УДК 343.1(477)

DOI https:/ / doi.org/10.32837 / yuv.v0i4.971

I. Курбатова,

кандидат юридичних наук,

старший прокурор

Прокуратури м. Києва

\title{
РОЛЬ ОРГАНІВ ПРОКУРАТУРИ В СИСТЕМІ ЗАПОБІГАННЯ ТА ПРОТИДІЇ КОРУПЦІї
}

Найбільшою перепоною до економічного зростання та демократичного розвитку держави, здатною поставити під загрозу будь-які позитивні зрушення і перетворення $€$ корупція, яка нівелює засади верховенства права та законності, заважає повноцінній реалізації гарантованих Конституцією прав та свобод громадян, всебічному розвитку громадянського суспільства створює негативний імідж української держави на міжнародній арені.

Важливу роль у розв'язанні проблеми протидії корупції, яка залишається одним із найактуальніших та найважливіших аспектів діяльності кожної держави, відіграють органи прокуратури, які покликані забезпечити невідворотність притягнення до кримінальної відповідальності за вчинене кримінальне правопорушення. Це питання завжди виступало одним із ключових компонентів кримінальної політики у будь-якій державі. Забезпечення його результативності реалізації щодо осіб, які вчинили корупційні злочини у сфері службової та професійної діяльності, відіграє неабияке значення для сьогоднішнього суспільства через його вкрай негативне ставлення до цих явищ.

Згідно з дослідженнями індексу СРI (Corruption Perception Index, Індекс сприйняття корупціi) міжнародної організаціі Transparency International, за 2018 рік Україна здобула лише 32 бали зі 100 можливих у цьому дослідженні, отримавши лише два додаткових бали, порівняно з 2017 роком, та піднялася зі 130 на 120 місце в глобальному рейтингу «Індексу сприйняття корупції» 3 посеред 175 досліджуваних країн світу. Поряд з цим показники України досі гірші ніж у країн сусідів: Польща 60 , Румунія - 47, Угорщина - 46, Білорусь - 44, Молдова - 33 .

На думку Європейської бізнес асоціації корупція та недовіра до судової системи в Україні вже третій рік поспіль очолюють рейтинг найголовніших перешкод для іноземних інвесторів [1].

Указане прямо пов'язано з неповнотою i фрагментарністю проведення антикорупційної реформи, у тому числі в частині діяльності правоохоронних органів. Саме ефективність реформування прокуратури України в умовах тотального правового нігілізму та корупціï прямо визначає перспективи зміцнення правопорядку й законності, стає базовим чинником позитивної динаміки суспільних процесів.

У цих умовах досить актуальним $€$ дослідження правової природи спеціалізації органів прокуратури із зверненням уваги на переваги, а також на можливі недоліки. Тему діяльності спеціалізованих органів прокуратури щодо протидії корупційним проявам в Україні досліджували: П.П. Андрушко, O.M. Бандурко, Ю.В. Баулін, B.I. Галаган, В.M. Гаращук, О.В. Драган, Д.Г. Заброда, Л.Є. Кисіль, М.В. Косюта, О.Р. Михайленко, М.В. Руденко, В.В. Сухонос, В.Я. Тацій, О.М. Толочко й інші відомі вітчизняні учені.

Однак аналіз практичних переваг i потенційних недоліків спеціаліза- 
ціï органів прокуратури потребують подальших досліджень і сьогодні.

Виходячи 3 наведеного, метою статті $є$ на підставі узагальнення чинного кримінального процесуального законодавства, практики його застосування та аналізу спеціальної літератури визначити роль органів прокуратури у кримінальних провадженнях щодо корупційних злочинів у сфері службової діяльності та професійної діяльності.

Відповідно до ст. 1 Закону України «Про запобігання корупціï» [2], корупція це використання особою наданих їй службових повноважень чи пов'язаних 3 ними можливостей 3 метою одержання неправомірної вигоди або прийняття такої вигоди чи прийняття пропозиції такої вигоди для себе чи інших осіб або відповідно пропозиція чи надання неправомірної вигоди особі, зазначеній у частині першій ст. 3 цього Закону, або на їі вимогу іншим фізичним чи юридичним особам 3 метою схилити цю особу до протиправного використання наданих їй службових повноважень чи пов'язаних 3 ними можливостей.

Прокуратура України посідає центральне місце в системі правоохоронних органів України у сфері протидії корупційним проявам. Вона здійснює цю протидію шляхом реалізації функцій процесуального керівництва досудовим розслідуванням та підтримання державного обвинувачення в суді, представницьку діяльність у позакримінальній сфері, координацію дій правоохоронних органів у сфері протидіï кримінальним корупційним проявам. Окремі елементи протидії корупційним проявам наявні також і під час реалізації функції нагляду за виконанням судових рішень у кримінальних провадженнях, застосування інших заходів примусового характеру, що обмежують гарантовані Конституцією права та свободи громадян.

На думку О.Р. Михайленка, органи прокуратури, кожен у межах своєї компетенції, відіграють реальну й конкретну роль у виконанні завдань і здійсненні функцій, покладених на прокуратуру. Іх система та структура побудовані так, щоб вплив прокуратури на забезпечення законності, правопорядку, прав і законних інтересів був ефективним, всеохоплюючим на всій території України і на всіх напрямах соціальних відносин, урегульованих законами [3, с. 58].

Особливу роль органів прокуратури у протидії корупції відіграє координація діяльності правоохоронних органів. Указана функція в процесі реформування органів прокуратури зазнала значних змін. Так, відповідно до ст. 10 Закону України «Про прокуратуру» від 05.11.1991р., на Генерального прокурора України та підпорядкованих йому прокурорів з метою підвищення ефективності протидії злочинності й корупції було покладено обов'язок координувати діяльність правоохоронних органів у питаннях протидії злочинності та корупції. Тобто, корупція розглядалася законодавцем як самостійний об'єкт координаційної діяльності поряд із координацією протидії злочинності.

Що стосується координаційної діяльності передбаченої ч. 2 ст. 25 чинного Закону України «Про прокуратуру», то в цій статті корупція є об'єктом координаційної діяльності виключно в «срері протидії злочинності» [4]. Тобто, законодавець виключив із координаційних повноважень прокуратури тих суб'єктів, які діють поза межами кримінального провадження. Фактично це може призвести до розбалансування системи протидії корупції й неузгодженості дій окремих антикорупційних інституцій, як наслідок, погіршення стану законності та правопорядку в державі. Так, в Законі зовсім нічого не сказано про взаємодію з Національним агентством з питань запобігання корупції, яке теж має право ініціювати вжиття заходів щодо притягнення до відповідальності осіб, винних у вчиненні корупційних або пов'язаних з корупцією правопорушень. 


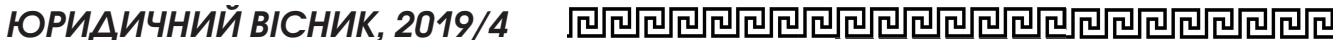

Важливим етапом реформування системи органів прокуратури України стало створення Спеціалізованої антикорупційної прокуратури (далі САП), статус якої унормовано ч. 5 ст. 8-1 Закону України «Про прокуратуру». Функціональне навантаження цього самостійного структурного підрозділу Генеральної прокуратури України включає як кримінальну так і позакримінальну сфери: САП здійснює нагляд за діяльністю Національного антикорупційного бюро України (далі - НАБУ) та позовну діяльність за наслідками кримінальних проваджень.

На думку I.В. Драгана, під час створення САП Україною було використано досвід передових європейських країн, таких як Німеччина, де в прокуратурах окремих земель можуть створюватися спеціальні відділи по боротьбі 3 корупцією (зокрема це відповідний відділ у прокуратурі м. Вупперталь, спеціалізована прокуратура по боротьбі 3 корупцією землі Північний Рейн-Вестфалія) [5, с. 51].

Як зазначає Проневич О.С. подібна практика існує в Іспаніі (Служба державного обвинувачення 3 протидіі корупції та організованій злочинності), в Румунії (Національний антикорупційний директорат у системі прокуратури при Вищому касаційному суді), в Швеції (Національний антикорупційний відділ у складі прокуратури Швеціі)тощо тощо [6, с. 263-265].

У 2002 році урядом Польщі затверджено програму боротьби з корупцією під назвою «Антикорупційна стратегія». На виконання цієї програми створена та працює надзвичайна кодифікаційна комісія сейму Польщі, яка готує зміни до законодавства з метою покращення протидії корупції.

324 серпня 2006 року набрав чинності Закон про «Про центральне антикорупційне Управління» (даліЦАУ). Основною метою діяльності ЦАУ $є$ боротьба зі зловживанням владою та використання привілеїв для досягнення особистої і майнової користі, а також діяльністю, спрямованою проти економічних інтересів держави. На ЦАУ покладено обов'язок переслідувати корупційну злочинність, ретельно перевіряти майнові деклараціi чиновників та працівників сфери самоуправління, слідкувати за спробами порушити заборону поєднання громадських (державних) функцій із господарською діяльністю. Зазначена система дозволяє також досить ефективно виявляти корупційні дії представників влади та вести ефективну боротьбу з ними[7, с. 202].

Естонія - це одна із країн пострадянського простору, яка вважається однією 3 найменш корумпованих у Європі, хоча в 90-х роках теж була поширена організована злочинність, «рекет» і корупція, зокрема і в правоохоронних органах. Починаючи з 1991 року, уряд країни розробив стратегію на побудову інноваційної моделі електронної держави, що супроводжувалося прийняттям нового антикорупційного законодавства. У протидії корупції державна прокуратура Естонії здійснює нагляд за працівниками правоохоронних органів [7, с. 201]

В Україні цей процес теж не стоїть на місці. Так Законом України «Про внесення змін до Закону України «Про прокуратуру» щодо забезпечення прозорості в організації діяльності Спеціалізованої антикорупційної прокуратури з метою виконання рекомендацій Міжнародного валютного фонду» від 18 лютого 2016 р. було запроваджено низку нововведень, якими підвищено ступінь незалежності Спеціалізованого антикорупційного прокурора від Генерального прокурора України, а також змінено процедуру призначення на керівні посади в САП. Зокрема, від компетенції Генерального прокурора України вилучено право призначення керівників і заступників керівників структурних підрозділів САП і передано відповідні повноваження Спеціалізованому антикорупційному прокуророві.

Ще одна новела яка посилила незалежність Спеціалізованого антикоруп- 
ційного прокурора від Генерального прокурора України стало те, що ключову роль у призначенні самого Спеціалізованого антикорупційного прокурора із цього часу відіграє конкурсна комісія, оскільки кандидатура, відібрана нею, призначається на посаду Генеральним прокурором України в обов'язковому порядку.

Крім того, Законом України «Про Національне антикорупційне бюро України» від 14 жовтня 2014 року, окрім норм, що стосуються організації діяльності НАБУ, викладено в новій редакції ст. 75 KК України, згідно 3 якою унеможливлюється застосування інституту звільнення від призначеного судом покарання 3 випробуванням щодо осіб, які засуджені за корупційні злочини, а також внесено зміни до ст. 66 КК України, якими заборонено застосування ст. $75 \mathrm{KK}$ Украіни до осіб, які вчинили злочини цього виду. Водночас, статтю 45 KK України доповнено приміткою, в якій викладено виключний перелік злочинів, що вважаються корупційними. Зрозуміло, що ці доповнення набагато підвищать ефективність протидії корупційним злочинам та покращать взаємодію НАБУ i САП.

Окремо слід зупинитись на співпраці України з європейськими інституціями щодо протидії корупції. На сьогодні Україною ратифіковано ключові конвенції з протидії корупції, зокрема Кримінальну та Цивільну конвенції Ради Європи про боротьбу з корупцією (ETS 173 та ETS 174), що дозволило приєднатися до GRECO. GRECO покликана удосконалювати компетентність іï членів в боротьбі з корупцією для вжиття заходів через динамічний процес спільного оцінювання методів проведення та однакового впливу згідно з їхніми зобов'язаннями в цій сфері.

На 84-му пленарному засіданні Групи держав Ради Європи проти корупціï (GRECO), проведення якого заплановано протягом 2-6 грудня 2019 року в м. Страсбург (Франція), Україна звітуватиме про виконання рекомендацій GRECO, наданих Україні за результатами 4-го раунду оцінювання по темі «Запобігання корупції серед парламентарів, суддів та прокурорів» (Звіт затверджений на 76-му пленарному засіданні GRECO, що відбулося 19-23 червня 2017p.).

Українською державою також виконано рекомендації Ради Європи щодо вдосконалення системи протидії корупціï, які безпосередньо не стосуються прокуратури, але опосередковано впливають на неї. Так, 11 листопада 2015 р. парламентом України прийнято Закон України «Про Національне агентство України з питань виявлення, розшуку та управління активами, одержаними від корупційних та інших злочинів», яким створено орган, що здійснює відповідні функції щодо активів, на які може бути накладено арешт або які може бути конфісковано в кримінальному провадженні. Верховною Радою України ухвалено Закон України «Про внесення змін до Кримінального та КПК України щодо виконання рекомендацій, які містяться у шостій доповіді Європейської комісії про стан виконання Україною Плану дій щодо лібералізації Європейським Союзом візового режиму для України, стосовно удосконалення процедури арешту майна та інституту спеціальної конфіскації від 18.02.2016p., а також інші нормативні акти. Вищезазначені закони також тією чи іншою мірою регулюють прокурорську діяльність у сфері протидії корупції.

Водночас прокуратура України на сучасному етапі зустрічається 3 низкою проблем, зумовлених незавершеністю антикорупційної реформи й організаційними недоліками. Однією з проблем є недостатня узгодженість між НАБУ, САП, ДБР і Генеральною прокуратурою України під час передання кримінальних проваджень від органів прокуратури до НАБУ чи ДБР, що пов'язано 3 недостатньою законодавчою визначеністю цієї процедури; визначення джерел матеріально-технічного постачання САП (такі 


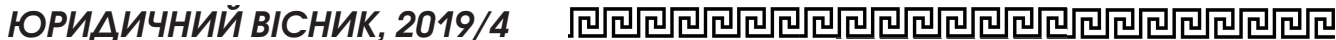

джерела можуть бути пов'язані як із НАБУ, так і з Генеральною прокуратурою) тощо.

Крім того, методика оцінки якості роботи прокурора застаріла та не відповідає оновленим завданням, які поставлені перед органами прокуратури. У зв'язку з цим наказом Генерального прокурора від 05 березня 2018 року № 38 створено робочу групу, на яку покладено обов'язок опрацювання можливості запровадження пілотного проекту системи оцінки якості роботи прокурора у прокуратурах Львівської, Одеської та Харківської областей та розробку проектів відповідних організаційно-розпорядчих документів.

Отже, прокурорська діяльність у сфері протидії корупції в Україні на сучасному етапі знаходиться на стадіiі удосконалення, що зумовлено необхідністю приведення національної правоохоронної системи до європейських та міжнародних стандартів. 3 метою відповідності передовим світовим моделям протидії корупції було прийнято комплекс нормативно-правових актів, які запровадили принципово нові засади діяльності органів прокуратури у цій сфері.

Україною було виконано значну частину рекомендацій інституцій $\in C$, ураховано досвід розвинутих країн Європи щодо протидії корупції та проведено заходи, які значно посилили антикорупційну діяльність та відмічається позитивна динаміка. Водночас прокуратура України продовжує наражатись на низку проблем, таких як недостатня урегульованість сплати судового збору, недосконалість механізму взаємодії з іншими суб'єктами протидії корупції: НАБУ, ДБР, Національне агентство з питань запобігання корупції тощо.

y cmammi проаналізовано стан протидї̈ корупиї в Україні та роль органів прокуратури в організаціі протидіі иим проявам. Наголошено, що на сьогодні стан протидіi корупиіі досить низький у порівнянні з розвиненими європейськими країнами, що заважає повноцінній реалізації гарантованих Конституцією прав та свобод громадян, всебічному розвитку громадянського суспільства створюе негативний імідж украйнської держави на міжнародніü арені.

Основна мета роботи полягає у тому, щоб на підставі узагальнення чинного кримінального прочесуального законодавства, практики його застосування та аналізу спеціальної літератури визначити роль органів прокуратури у кримінальних провадженнях щзодо корупційнuх злочинів.

Сформульовано, що Україна використала досвід передових європейських країн у протидіі корупції та з иією метою було внесено зміни у чинне кримінальне та кримінальне процесуальне законодавство, а також створені та унормована діяльність таких органів як САП, НАБУ, НАЗК, ДБР, на які покладено обов'язок організації та здійснення заходів щодо протидії корупиійним проявам та реагування на вчинені корупційні злочини.

Крім того приділена значна увага співпраці України з європейськими інституціями щзодо протидї̈ корупиіï. Наголошено, що українська держава виконала значнии обсяг рекомендацій європейських інституиій, що дозволило приєднатися до GRECO $i$ як наслідок покращило співпрацюю з EC у питаннях протидіi корупиіï.

Підкреслено, щзо на сьогодні ще не повністю закінчено всі заходи, які направлені на реформування правоохоронної системи Украйни з метою покращення ефективності протидіi корупиіï $i$ цей процес необхідно удосконалювати враховуючи европейські та світові тендениіï.

Ключові слова: прокурор, органи прокуратури, корупція, корупційні злочини, протидія корупції. 


\section{Kurbatova I., ROLE OF PROSECUTOR BODIES IN THE SYSTEM OF PREVENTION AND ANTI-CORRUPTION}

The article analyzes the state of counteracting corruption in Ukraine and the role of prosecutors in organizing counteraction to these manifestations. It is emphasized that today the state of counteraction to corruption is rather low in comparison with the developed European countries, which hinders the full realization of the rights and freedoms guaranteed by the Constitution of the citizens, the comprehensive development of civil society creates a negative image of the Ukrainian state in the international arena.

The main purpose of the work is to determine, on the basis of the generalization of the existing criminal procedural legislation, the practice of its application and analysis of the specialized literature, the role of the prosecuting authorities in criminal proceedings concerning corruption offenses.

It is stated that Ukraine has used the experience of the leading European countries in the fight against corruption and for this purpose it has been amended the existing criminal and criminal procedural legislation, as well as created and standardized activities of such bodies as the SAP, NABU, $N A Z C, D B R$, which are responsible. organization and implementation of measures for combating corruption and responding to the crimes committed.

In addition, considerable attention is paid to Ukraine's cooperation with the European institutions in combating corruption. It was stressed that the Ukrainian state has implemented a considerable amount of recommendations of the European institutions, which allowed it to join GRECO and as a consequence improved cooperation with the EU in the fight against corruption.

It is emphasized that today all measures aimed at reforming Ukraine's law enforcement system with the aim of improving the effectiveness of combating corruption have not been fully completed, and this process needs to be refined in the light of European and world trends.

Key words: prosecutor, prosecuting authorities, corruption, corruption crimes, counteraction to corruption.

\section{Література}

1. Національна доповідь щодо реалізації засад антикорупційної політики у 2018 році: Схвалена Рішенням Національного агенства з питань запобігання корупuiii 29.03.2019p. №885. URL: https: / / nazk. gov.ua/wp-content / uploads / 2019/07 / Natsdopovid-2018.pdf

2. Про запобігання корупції: Закон України від 14 жовтня 2014p. № 1700 VII URL: https: / / zakon.rada.gov.ua/laws / main / 1700-18

3. Михайленко О.P. Прокуратура Украіни: підручник. 2-ге вид., перероб. і допов. K.: Юрінком Iнтер, 2011. 336 c.

4. Про прокуратуру: Закон України № 1697-VII від 14.10.2014 p. / Caŭm Bepховної Ради України. URL: http: / / zakon4. rada.gov.ua/laws/show/1789-12.

5. Драган I.B. Роль прокуратури у протидії корупції: досвід Німеччини. Науковий часопис Національної академії прокуратури України. 2015. № 2. С. 49-55.

6. Проневич О.C. Iнститут спецуіалізованої антикорупційної прокуратури в європейській державно-правовій традиції. Форум права. 2015 № 1. С. 261-268.

7. Супрун Т.М. Зарубіжний досвід запобігання та протидії корупиії. Міжнародний юридичний вісник: актуальні проблеми сучасності (теорія та практика) Випуск № 2-3(6-7). 2017. C. 199-204.

8. Грицюк I. В. Криміналістична характеристика кримінальних корупційних правопорушень. Реформування кримінального провадження в Україні: кримінальні процесуальні та криміналістичні аспекти: матер. Міжнар. наук.-практ. конф. присвячена пам'яті професорів В. П. Бахіна, В. К. Лисиченка, І. Я. Фрідмана, 19 квітня 2019 р. / Ун-m ДФС України, Нац. академія внутрішніх справ, Наи. академія служби безпеки України /ma ін.]. Iрпінь, 2019. C. $345-348$. 